RESEARCH NOTES

\title{
On The Formation of the Pedagogical Culture of Future Mathematics Teachers in the Context of the Implementation of the Competence- Based Approach
}

\section{Sobre la formación de la cultura pedagógica de los futuros profesores de matemáticas en el contexto de la implementación del enfoque por competencias}

Sadykova Elena Rashidovna

Associate Professor, N.I. Lobachevsky Institute of Mathematics and Mechanics (Department of theory and technology of teaching mathematics and computer science), Kazan Federal University

ORCID: 0000-0001-5056-7134

\section{Razumova Olga Viktorovna}

Associate Professor, N.I. Lobachevsky Institute of Mathematics and Mechanics (Department of theory and technology of teaching mathematics and computer science), Kazan Federal University ORCID: 0000-0002-0292-1108

\section{Nasibullov Ramis Rafagatovich}

Associate Professor, Institute of Psychology and Education (Department of Training and Education Methodology), Kazan Federal University

ORCID: 0000-0002-0382-3235

Yarullin Ilnar Fagimovich

Associate Professor, Institute of Psychology and Education (Department of Training and Education Methodology), Kazan Federal University

ORCID: 0000-0002-5040-6530

* Correspondence

Email: sadikova_er@mail.ru

\section{Citation:}

Sadykova Elena Rashidovna, Razumova Olga Viktorovna, Nasibullov Ramis Rafagatovich, Yarullin Ilnar Fagimovich. (2021). On The Formation of the Pedagogical Culture of Future Mathematics Teachers in the Context of the Implementation of the Competence- Based Approach. Propósitos y $\begin{array}{lll}\text { Representaciones, } & 9 \text { (SPE2), }\end{array}$ http://dx.doi.org/10.20511/pyr2021.v9nSPE2.1078 


\begin{abstract}
The relevance of the problem under study is due to the need to modernize the professional training of future teachers in the context of the implementation of the competence approach. One of the most effective methods for improving the training of a modern teacher is his subject and methodological training. In modern times, competitive teachers are in demand, possessing the necessary and sufficient types of professional activity, a high level of pedagogical culture. In the process of studying the formation of pedagogical culture, there was an elected teacher of mathematics. In the focus of the problems of the formation of the pedagogical culture of the future teacher, the problems of the formation of the pedagogical culture in the context of the implementation of the competence approach, associated with the specificity of the formation of the pedagogical culture of the teacher of mathematics, remain insufficiently studied. The article shows the content of the structural components of the teacher's pedagogical culture, developed and implemented the conditions for the formation of the pedagogical culture of the future mathematics teacher in the context of the competence approach. The leading research technologies are metacognitive technologies of a reflexive character with the means of information and communication technologies. The following methods were used in the study: theoretical (analysis of philosophical, psychological and pedagogical literature on the problem of research, study of mass and generalization of advanced pedagogical experience, pedagogical modeling), empirical (pedagogical observation, conversation, questionnaire, interviewing, testing). The materials of the article can be useful to future mathematics teachers, graduate students, teachers of higher educational institutions interested in the formation of teacher's pedagogical culture, and professional training of subject specialists.
\end{abstract}

Keywords: pedagogical culture, humanistic pedagogical position, psychological and pedagogical competence, creative potential, pedagogical skills, culture of professional and pedagogical communication.

\title{
Resumen
}

La relevancia del problema en estudio se debe a la necesidad de modernizar la formación profesional de los futuros docentes en el contexto de la implementación del enfoque por competencias. Uno de los métodos más eficaces para mejorar la formación de un profesor moderno es su formación temática y metodológica. En los tiempos modernos se demandan profesores competitivos, que posean los tipos de actividad profesional necesarios y suficientes, un alto nivel de cultura pedagógica. En el proceso de estudiar la formación de la cultura pedagógica, hubo un maestro electo de matemáticas. En el foco de los problemas de la formación de la cultura pedagógica del futuro docente, los problemas de la formación de la cultura pedagógica en el contexto de la implementación del enfoque competencial, asociados a la especificidad de la formación de la cultura pedagógica de el profesor de matemáticas, siguen siendo insuficientemente estudiados. El artículo muestra el contenido de los componentes estructurales de la cultura pedagógica del docente, desarrolló e implementó las condiciones para la formación de la cultura pedagógica del futuro docente de matemáticas en el contexto del enfoque por competencias. Las tecnologías de investigación punteras son tecnologías metacognitivas de carácter reflexivo con los medios de las tecnologías de la información y la comunicación. En el estudio se utilizaron los siguientes métodos: teórico (análisis de literatura filosófica, psicológica y pedagógica sobre el problema de la investigación, estudio de masa y generalización de la experiencia pedagógica avanzada, modelado pedagógico), empírico (observación pedagógica, conversación, cuestionario, entrevistas, pruebas). Los materiales del artículo pueden ser de utilidad para futuros profesores de matemáticas, estudiantes de posgrado, profesores de instituciones de educación superior interesados en la formación de la cultura pedagógica del profesorado y la formación profesional de especialistas en la materia.

Palabras clave: cultura pedagógica, cargo pedagógico humanista, competencia psicológica y pedagógica, potencial creativo, habilidades pedagógicas, cultura de la comunicación profesional y pedagógica. 


\section{Introduction}

The changes that occur in the educational space make high demands on the professional training of future teacher in the context of the implementation of the competence approach (Kamalova \& Zakirova, 2015; Zakirova, 2016). The problem of professional training of an expert occupies an important place in many universities of the world: the programs based on active learning methods centered on the student are implemented (Kolmos \& Fink, 2004), the issue of implementing "reflection on the ethical obligations and social consequences of each profession" by the university is raised (Rhodes, 2001), attention is paid to the innovative technologies, the implementation of integration ties (Andreev, 2013; Razumova et al., 2018; Razumova et al., 2017). The role of the teacher in modern education is not determined only by the transfer of a certain set of knowledge, information and practical experience, but consists in the formation of professional competencies implemented on the basis of a competent approach (Bekoeva et al., 2018; Lytras et al., 2020). The current situation changes the requirements for a modern teacher, in particular, the teacher of mathematics, for his professional training.

In modern scientific research, the opinion is increasingly strengthened that mathematics should become an important means of humanizing the education and socialization of personality (Mordkovich, 1985; Shadrikov, 2002). It is increasingly considered as a humanitarian, general cultural discipline that fosters the formation of a person's spiritual culture (Testov, 2001). in the context of the implementation of the competence approach, one of the most important conditions for realizing the cultural potential of mathematics as a teaching discipline is, in our opinion, the formation of a pedagogical culture of a mathematics teacher (Sadykova, 2003). The aim of the study is to consider the main components and develop the conditions for the formation of pedagogy of the culture of the future of mathematics in the context of the implementation of the competence approach.

\section{Methods}

We used the following methods and approaches during the study: system approach for disclosing the problem's essence; classification, systematization, generalization of pedagogical experience on the problem studied; observation, comparison, questioning; analysis of the results obtained.

The study was conducted with the students of the pedagogical department of the Institute of Mathematics and Mechanics named after N.I. Lobachevsky of the Kazan (Volga) Federal University, the teachers of the schools of the Republic of Tatarstan.

\section{Results and Discussion}

A significant number of studies have been devoted to various aspects of the content of pedagogical culture: (Z.F.Abrosimova, E.N.Bogdanova, E.V.Bondarevskaya, T.V.Ivanova, L.B.Sokolova, L.A.Terekhina) (Sadykova et al., 2012). Scientists also considered certain aspects of the teacher's pedagogical culture: methodological culture (V.V.Krayevsky, N.D.Nikandrov, V.A.Slastenin), moral and aesthetic culture (E.T.Ardashirova, N.B.Krylova), communicative culture (T.N.Levashova, A.V.Mudrik), technological culture (N.V.Kuzmina, N.F.Talyzina), spiritual culture (B.Z.Vulfov, B.T.Likhachev, N.D.Nikandrov, N.E.Shchurkova et al.) (Sadykova, 2003). The teachers play a big role in tolerance formation in the modern information and communication society (Beysenbaeva et al., 2013).

The role and essence of the concept of "pedagogical culture" was first considered in the late 50s of the XX century by G.N. Volkov within the framework of ethnopedagology. In his opinion, "this is the medium of the material and spiritual culture of the people, which is directly related to the upbringing of children" (Sadykova, 2003).

At the present stage pedagogical culture is considered as part of the universal culture, which is the content of the basic pedagogical civilizations and educational paradigms (A.I.Arnoldov, M.VBoguslavsky) (Sadykova, 2003); as a social and pedagogical phenomenon, a 
mean of environmental education (V.M.Danilchenko, G.I.Rizz); as a manifestation of the essential properties of the individual, professional activity and communication (A.V.Barabanshchikov, T.V.Ivanova, I.F.Isaev, A.I.Piskunov); as a multilevel complex pedagogical phenomenon (V.L.Benin, I.E.Vidt) (Sadykova et al., 2012).

The modern science considers the teacher's pedagogical culture as a synthesis of natural and acquired personal properties that ensure a high level of the teacher's activity (Sadykova, 2003). The humanistic model of pedagogical culture of the teacher, which, in our opinion, is invariant in relation to the teachers of any subject specialization, which is determined by the unity of the humanistic approach to the educational process was developed by the efforts of E.V.Bondarevskaya, T.V.Belousova, E.Yu.Zakharchenko, S.V.Kulnevich et al. (Bondarevskaya \& Kulnevich, 1999). At the same time, the pedagogical culture of the teacher of a particular subject is a kind of subject-activity and subject-personal concretization of a single humanistic model, which does not exclude a certain change in the structure of this model, determining the arrangement of certain accents on any of the components of pedagogical culture depending on the specific nature of the teacher's activity (Sadykova et al., 2012).

The tasks of training teachers of various specialties of the competence approach require an analysis of the specifics of the pedagogical culture of the subject teacher, which embodies the features of his thinking and outlook, pedagogical communication and activity, and professional characteristics of the individual. The defining and system-forming component of the pedagogical culture of the teacher of mathematics is the expressed humanistic pedagogical position of the teacher - the main source of cultural influences on the students (Sadykova, 2003).

Taking a single humanistic model of pedagogical culture as a basis, it is expedient, at the same time, to distinguish its subject-content, operational-activity and personality-oriented side. It is necessary to add respectful, interested, emotionally-saturated, deeply aware attitude to the subject to the general system of teacher's relations with students, their social and educational mission. In our opinion, it should include: understanding the socio-cultural and practical role of mathematics and mathematical education in the life of modern society; understanding the close relationship of mathematics with other sciences, its methodological role in the modern system of scientific knowledge; understanding the cultural and educational role of mathematics in the formation of the personality of students, in the formation of a system of mathematical knowledge, skills, a mathematical worldview, in the development of mathematical thinking; understanding the developing function of mathematics, mathematical education in the development of mental and cognitive abilities of the individual, the processes of perception, memory and thinking .

The second component of the pedagogical culture of the teacher of mathematics is the totality of humanistically oriented professionally significant personal qualities. These qualities are mediated by the specific features of the activity of the teacher of mathematics, determined by the peculiarities of the given academic subject. In our opinion, the third component of the pedagogical culture of the teacher of mathematics is his education in the field of mathematics, a professionalpedagogical vision of his subject, the ability to interpret his material for the pedagogical purposes. The modern teacher should possess innovative methods of searching, processing and using information, be able to interpret and adapt scientific information, know the forms and methods of scientific knowledge, and master different ways of mathematical knowledge .

The fourth component is his psychological and pedagogical competence, theoretical and practical readiness for the implementation of pedagogical activity, in particular, educational and extracurricular work in mathematics. One of the elements is a system of psychological and pedagogical knowledge. In the general structure of the psychological knowledge of the teacher of mathematics, a particular role is played by the specific psychological knowledge of the features of forming the mathematical representations and concepts, in particular, geometric spatial representations or extremely formalized algebraic concepts; knowledge of psychological features of the formation of specific mathematical skills, for example, methods of working upon studying the number system, methods of solving the arithmetic problems "on processes". 
The independent component of the general system of psychological and pedagogical knowledge of the teacher of mathematics is a variety of methodological and technological knowledge, reflecting the specifics of methods and means of teaching mathematics, especially the study of certain educational sections and topics.

The culture of pedagogical thinking of the teacher of mathematics has also an objective component, the focus on solving the pedagogical problems of teaching students, learning mathematics - on their analysis and diagnosis, on highlighting the key problem.

The fifth component of the pedagogical culture of the teacher of mathematics is his creative pedagogical potential, the experience of creative pedagogical activity. One of the most important criteria of qualification of a modern teacher, in particular, a teacher of mathematics, is his creative activity. The main mean of forming creative activity is a set of educational and methodological tasks, the implementation of the principle of variability in the search for solving the mathematical problems. The principle of variability of the search for solving mathematical problems causes the actualization of the diverse knowledge of students from various fields of mathematics and their inclusion in the search for non-standard solutions of the proposed known problems.

The next component of the pedagogical culture of the teacher of mathematics is the culture of professional-pedagogical communication and behavior. Modern understanding of the nature of professional and pedagogical communication emphasizes its dialogical, subject-subjective nature, the focus on the development of the personality of students. Therefore, one of the leading principles of pedagogical communication and behavior should be the principle of continuous feedback, orientation to the real interests and capabilities of the students (Haines, 2016).

For the effective formation of the components of the pedagogical culture of future mathematics teachers in the context of a competence-based approach, experimental work was carried out. The research was carried out in three stages. The purpose of the ascertaining experiment was to identify the initial level of the formation of pedagogical culture. At this stage, the methods of pedagogical observation, conversation, questioning, interviewing, testing, and control survey were used. By the method of expert assessment, the most typical study groups were selected, in which students were surveyed. In total, 57 departments of pedagogical education of the Institute of Mathematics and Mechanics named after N.I. Lobachevsky KFU. At this stage, it was found that the students have insufficiently formed such components of pedagogical culture as professionally significant personal qualities of a teacher and his creative potential. The general requirements of a cultural and pedagogical nature are poorly implemented in the process of general cultural, psychological, pedagogical and subject training. The survey revealed a weakness among students about the structure of the teacher's pedagogical culture, the narrowness of extracurricular interests and spiritual students, shortcomings in the development of the culture of pedagogical thinking, communication and learning, the need to form their own pedagogical culture. Many students have insufficiently clearly expressed professional orientation, interest in learning, and a desire for self-education. The results of the ascertaining experiment showed a relatively low level of formation: $61.2 \%$ of all surveyed passed a low level, $31.7 \%$ - an average level, and only $7.1 \%$ a high one. The results obtained demonstrated poor formation of the cognitive component. Most of them (over 60\%) have poorly perceived structural components of pedagogical culture. The results of the ascertaining experiment show the need to organize purposeful, systematic and consistent work to form the components of pedagogical culture in the context of a competence-based approach. The data of the theoretical analysis of the problems identified in the process of research of the emergence of the need to develop conditions that allow the purposeful formation of the pedagogical culture of future mathematics teachers in the context of the implementation of the competence approach.

The first condition for the formation is the integration of psychological, pedagogical, methodological and subject training of students (at the target, motivational and organizational and activity levels). It is integration that solves the problem of the inconsistency of teaching and educational work within the framework of individual academic disciplines, unites the teacher's 
practical subject-based activity on the basis of the psychological, pedagogical, methodological and subject, in particular, mathematical knowledge.

The second condition for the formation of the pedagogical culture of future mathematics teachers is the use of metacognitive technologies in synthesis with the means of information and communication technologies. In the process of preparing a future teacher, the use of metacognitive technologies contributes to the development of students' independence and creativity.

In the context of the competence-based approach, it is necessary to integrate classroom and extracurricular teaching and educational work, which is the third condition for the formation of the pedagogical culture of future mathematics teachers. The combination of various types of activities, such as educational, cognitive, play, quasi-professional, communicative, is able to ensure the adequate formation of professional competencies.

The fourth condition for the formation of pedagogical culture is associated with the implementation of the continuity of theoretical and practical professional training of future teachers. For many students, there is a gap between theoretical knowledge and the ability to apply it.

The fifth condition for the formation of a pedagogical culture of future mathematics teachers is the humanization of pedagogical communication and interaction, the organization of partnership relations, creative cooperation between teachers and students. Collaboration pedagogy is a special pedagogical technology, which is a system of pedagogical techniques and tools based on the principles of full-fledged interpersonal communication, mutual interest, respect and trust between the participants in pedagogical interaction.

In the course of the formative experiment, a system of measures was carried out for the integrated formation of pedagogical culture in the context of a competence-based approach.

As part of the implementation of the first condition, a system of pedagogical measures was implemented to integrate the psychological, pedagogical, methodological and subject training of students. In senior courses, students are given the opportunity, within the framework of elective courses, to master such disciplines as "The psychological foundations of teaching mathematics", "Modern means of assessing the quality of education", which integrate knowledge of psychology, mathematics, methodology, pedagogy.

As part of the implementation of the second condition in the educational process, metacognitive technologies were used with the means of information and communication technologies. So, when studying certain topics of the course "Technology and Methods of Teaching Mathematics", game simulation technologies were used, through which students evaluated their own actions and thoughts, using metacognitive skills formed earlier in solving problems, and becoming a special subject of analysis and assessment by classmates acting in the function a kind of "observers". As a result of such an assessment, the student gets the opportunity to realize his own metacognitive qualities and, if necessary, correct them. To implement the condition, the following directions were determined: organization of the educational process using gaming technologies, various forms of conducting classes (lecture-conference, webinars); development of projects by students using information technologies (sites, electronic resources). As part of the study of the discipline "Psychological foundations of teaching mathematics", students were offered case tasks that contribute to the formation of such components of pedagogical culture as creative thinking, psychological and pedagogical competence.

As part of the implementation of the third condition, in the course of the formative experiment, the integration of classroom and extracurricular teaching and educational work was consistently carried out. At this stage, the coordination of educational and extracurricular work of the Department of Theory and Technologies of Teaching Mathematics of Informatics of the Institute of Mathematics and Mechanics named after N.I. Lobachevsky Kazan Federal University and the Department of Training and Education Methodology at the Institute of Psychology and 
Education of the Kazan Federal University. Joint activities include integrated lessons on teaching methods of mathematics, joint conferences on teaching practice.

The implementation of the fourth condition was aimed at achieving the continuity of theoretical and practical training of students and required a comprehensive organization of students' activities, a dialectical combination of their educational and cognitive, educational and practical and independent practical activities. Educational and practical activity, synthesizing the cognitive and practical activities of students, organized both in the classroom and during the period of pedagogical practice in 4, 5 courses, acted as a system-forming component. In practice, such forms were used as organizing discussions, business games, modeling pedagogical situations, collective discussion and analysis of students' activities.

As part of the implementation of the fifth condition, a set of measures was carried out to humanize pedagogical communication and interaction, to organize partnership relations and creative cooperation between teachers and students. Here, methodological support was provided by personality-oriented pedagogical technologies. The result was the formation of communicative, personal components. At the stage of implementation of the developed conditions, forms of designing the types of professional activity were used in the context of his professional competence and the development of the creative personality of the future teacher (Sadykova, 2003; Boström \& Hallin, 2013; Thomas, 2012).

The task of the control stage of the study was to determine the effectiveness of the work carried out on the formation of the components of the pedagogical culture of students in the context of the competence-based approach. The results, confirmed by mathematical methods, indicate that there is a positive dynamics in the formation of components. The effectiveness of the experimental work was tested by comparative analysis of the results of the starting and final diagnostics of the level of formation of pedagogical culture. To ensure the reliability of the diagnostic results, a sample of students was carried out, ensuring the representativeness of the study - the correspondence of the characteristics obtained as a result of the selective study to the indicators characterizing the entire general population. As a result, the control and experimental groups were formed.

The data obtained during the experiment are presented in the diagrams.

Dynamics of changes in formation pedagogical culture (\%)

\begin{tabular}{|l|l|}
\hline Experimental group & The final stage \\
\hline The initial stage & \\
\hline $30,60 \%$ & \\
\hline \\
$=$ low level $=$ medium level $=$ high level \\
\hline Control group
\end{tabular}




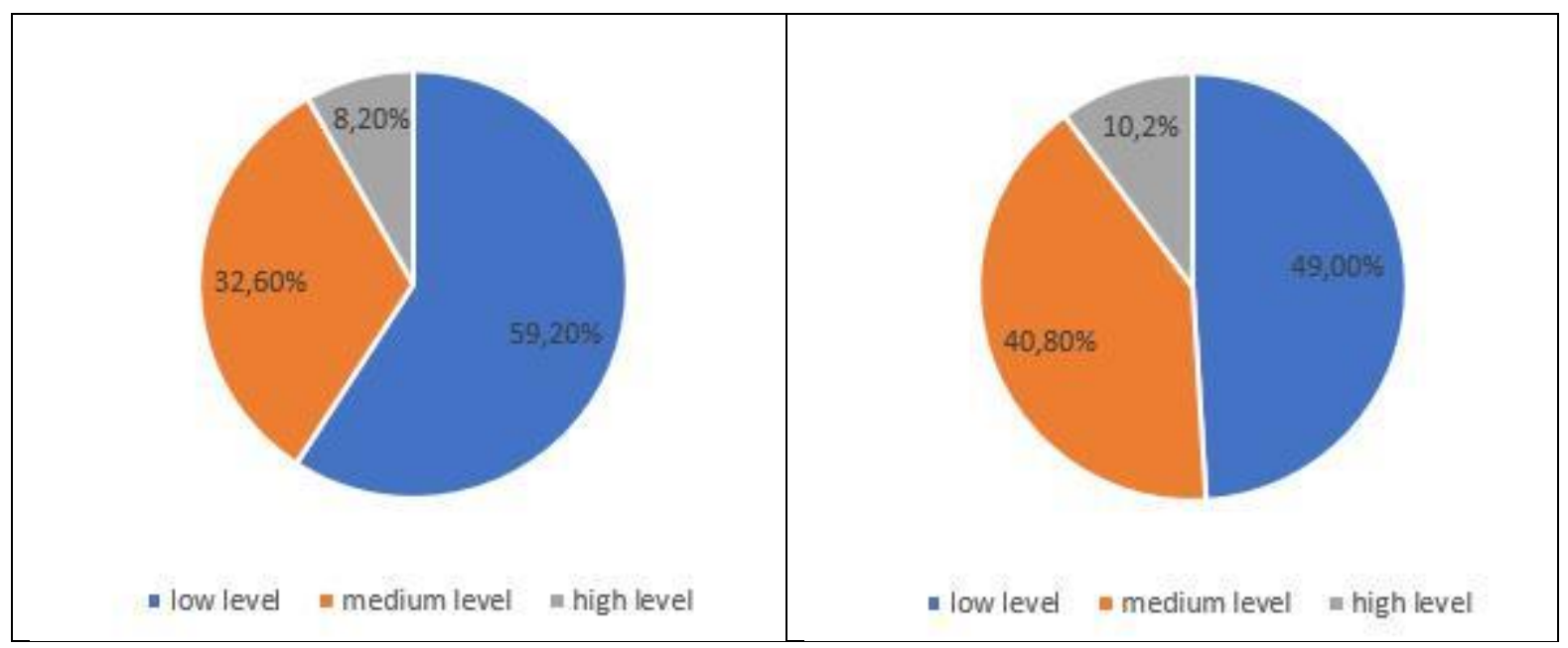

Initial diagnostics showed a clear predominance in real practice of higher education of students with a low level of formation of pedagogical culture (respectively, 63,3\% in the experimental groups and 59,2\% in the control groups). As a result of the comprehensive measures, the number of students with a low level of pedagogical culture formation decreased in the control groups on average from $59,2 \%$ to $49 \%$ (by $10,2 \%$ ), in the experimental groups - from $63,3 \%$ to $28,5 \%$ (by $34,8 \%$ ). The number of students with high and medium levels of pedagogical culture formation increased from $6,1 \%$ to $18,4 \%$, from $30,6 \%$ to $53,1 \%$ (in the control groups - from $8,2 \%$ to $10,2 \%$, from $32,6 \%$ to $40,8 \%$ ).

\section{Conclusion}

The study showed that for the process of forming the pedagogical culture of future mathematics teachers in the context of the competence-based approach, it is necessary to organize purposeful, systematic and consistent work using the synthesis of technologies of a metacognitive reflexive nature and means of information and communication technologies. The results obtained in the course of the work showed that, in the context of the competence-based approach, the implementation of the developed conditions for the formation of pedagogical culture increased the quality of professional training of future mathematics teachers. Students mastered such components of the teacher's pedagogical culture as: education in mathematics, psychological and pedagogical competence, culture of speech, thinking and communication, humanistic pedagogical position, professionally significant personal qualities of the teacher and his creative potential.

\section{Acknowledgements}

The work is performed according to the Russian Government Program of Competitive Growth of Kazan Federal University.

\section{References}

Andreev, V.I. (2013). Systematics of pedagogical and didactic laws integrally oriented to the guaranteed quality of education. Education and Self-Development, 3(37).

Bekoeva, M. I., Ambalova, S. A., \& Takhokhov, B. A. (2018). Universal humanitarian competencies as a basis for developing professional competence of a modern teacher/Универсальные гуманитарные компетенции как основа профессиональной компетентности современного педагога. Novosibirsk State Pedagogical University Bulletin, 8, 59-72.

Beysenbaeva, A. A., Bulshekbayeva, A. I., \& Ubniyazova, S. A. (2013). Educational and ideological culture of a teacher in forming tolerance. Middle East Journal of Scientific Research, 14(7), 920-924.

Bondarevskaya, E.V., \& Kulnevich, S.V. (1999). Pedagogical Culture. Pedagogy: Personality in the Humanistic Theories and Education Systems, Rostov-on-Don, 101-105. 
Boström, L., \& Hallin, K. (2013). Learning Style Differences between Nursing and Teaching Students in Sweden: A Comparative Study. International Journal of Higher Education, 2(1), 22-34.

Haines, K. (2016). Expanding the knowledge base of teachers' use of communication tools for language learning. System, 62, 102-112.

Kamalova, L. A., \& Zakirova, V. G. (2015). The formation of the pedagogical values of future primary school teachers at the University. Rev. Eur. Stud., 7, 1-9.

Kolmos, A., \& Fink, F. K. (2004). The Aalborg PBL model: progress, diversity and challenges. L. Krogh (Ed.). Aalborg: Aalborg University Press.

Lytras, M., Sarirete, A., \& Damiani, E. (2020). Technology-enhanced learning research in higher education: A transformative education primer.

Mordkovich, A.G. (1985). On the professional pedagogical orientation of mathematical training of students. Soviet Pedagogy, 12, 52-57.

Razumova, O. V., Sadykova, E. R., \& Yarullin, I. F. (2017). Modern Educational Technologies in Vocational Training of Future Teacher of Mathematics. Revista Publicando, 4(13 (2)), 419-428.

Razumova, O. V., Sadykova, E. R., \& Zamaliev, R. R. (2018). Meta-cognitive technologies in the training of students-future teachers. The Journal of Social Sciences Research, (Specialissue1), 468-472.

Rhodes, F. H. T. (2001). The creation of the future: The role of the American university. Cornell University Press.

Sadykova, E.R. (2003). Forming the Pedagogical Culture of Future Teachers of Mathematics by the Example of Prominent Representatives of the Kazan Mathematical School (19th - early 20th centuries): Thesis of the Candidate of Pedagogical Sciences, Kazan, 230 p.

Sadykova, E.R., Razumova, O.V., \& Timerbaeva, N.V. (2012). Features of Pedagogical Culture of the Teacher of Mathematics and the Ways of its Formation. Bulletin of the Northern (Arctic) Federal University. Series "Humanities and Social Sciences", Arkhangelsk, 5, 109-115.

Shadrikov, V.D. (Ed.). (2002). Training the Teacher of Mathematics: Innovative Approaches. M., $383 \mathrm{p}$.

Testov, V. (2001). Development of Spirituality - the Basis of Socio-Cultural Renewal of Mathematical Education. Mathematics. Supplement to the Newspaper "Pervoe Sentyabrya", 43, 1-3.

Thomas, G.P. (2012). Metacognition in Science Education: Past, present and future considerations", Second International Handbook of Science Education, Springer, Dordrecht, 131-144.

Zakirova, R. A. (2016). The Structure of Primary School Teachers' Professional Competence. International Journal of Environmental and Science Education, 11(6), 11671173 . 